University of Nebraska - Lincoln

DigitalCommons@University of Nebraska - Lincoln

Faculty Papers and Publications in Animal

Science

Animal Science Department

4-1-1983

\title{
SIMULATION OF BREED AND CROSSBREEDING EFFECTS ON COSTS OF PORK PRODUCTION
}

\author{
G. L. Bennett \\ University of Nebraska-Lincoln, gary.bennett@ars.usda.gov \\ W. M. Tess \\ University of Nebraska-Lincoln \\ G. E. Dickerson \\ University of Nebraska-Lincoln \\ R. K. Johnson \\ University of Nebraska-Lincoln, rjohnson5@unl.edu
}

Follow this and additional works at: https://digitalcommons.unl.edu/animalscifacpub

Part of the Animal Sciences Commons

Bennett, G. L.; Tess, W. M.; Dickerson, G. E.; and Johnson, R. K., "SIMULATION OF BREED AND CROSSBREEDING EFFECTS ON COSTS OF PORK PRODUCTION" (1983). Faculty Papers and Publications in Animal Science. 31.

https://digitalcommons.unl.edu/animalscifacpub/31

This Article is brought to you for free and open access by the Animal Science Department at DigitalCommons@University of Nebraska - Lincoln. It has been accepted for inclusion in Faculty Papers and Publications in Animal Science by an authorized administrator of DigitalCommons@University of Nebraska - Lincoln. 


\title{
SIMULATION OF BREED AND CROSSBREEDING EFFECTS ON COSTS OF PORK PRODUCTION ${ }^{1}$
}

\author{
G. L. Bennett ${ }^{2}$, W. M. Tess ${ }^{3}$, G. E. Dickerson ${ }^{4}$ and R. K. Johnson ${ }^{5}$ \\ University of Nebraska \\ and \\ US Department of Agriculture, \\ Lincoln, NE 68583-0908
}

\section{Summary}

A bio-economic model of swine production was used to simulate expected performance effects of breeds in alternative breeding systems on total costs $/ 100 \mathrm{~kg}$ of live weight (EWW) or $100 \mathrm{~kg}$ lean (ELW) for marketing at $100 \mathrm{~kg}$ live weight and on costs $/ 100 \mathrm{~kg}$ lean for marketing at mean $185-\mathrm{d}$ weight (ELA). Effects of heterosis and of six U.S. breeds were simulated for integrated industry purebred (P), two-breed specific (2S), backcross (2B) and rotation cross (2R), and three-breed specific (3S) and rotation cross (3R) breeding systems. Traits considered were age at puberty (-PUB), conception rate (CR), litter size born alive (NBA), preweaning viability (VIAB), milk production (MILK), age at $100 \mathrm{~kg}$ live weight (-DAYS) and empty body fat percentage (-FAT). Cost reductions from crossbreeding systems were greater for ELA than for ELW or EWW, ranging from -3 to $-5 \%$ for $2 S,-6$ to $-7 \%$ for $2 \mathrm{~B}$ and $2 \mathrm{R}$, and -7 to $-9 \%$ for $3 \mathrm{~S}$ and $3 R$. Reductions in nonfeed costs were much greater than those in feed costs for EWW and ELW ( -4 to $-12 \%$ vs -2 to $-4 \%$ ), and especially

\footnotetext{
${ }^{1}$ Published as Paper No. 6757, Journal Ser., Nebraska Agr. Exp. Sta., Lincoln.

${ }^{2}$ Postdoctoral Research Associate, Dept. of Anim. Sci., Univ, of Nebraska, Lincoln. Supported by Cooperative Agreement No. 3090-20372-013A of ARS, USDA, and Univ. of Nebraska. Present address: Ruakura Anim. Res. Sta., Ministry of Agr. and Fisheries, Hamilton, New Zealand.

${ }^{3}$ Graduate Assistant, Dept. of Anim. Sci., Univ. of Nebraska, Lincoln. Present address: Dept. of Anim. Sci., North Carolina State Univ., Raleigh 27650.

${ }^{4}$ Research Geneticist, Roman L. Hruska US Meat Animal Research Center, ARS, USDA, 225 Marvel Baker Hall, Univ. of Nebraska, Lincoln 68583-0908.

${ }^{5}$ Professor, Dept. of Anim. Sci., Univ. of Nebraska, Lincoln 68583-0908.
}

for ELA ( -9 to $-17 \%$ vs -1 to $-2 \%$ ). Order of maternal trait importance in ranking breeds was NBA, VIAB, CR, MILK and -PUB for P, 2R and $3 R$ systems and as maternal breeds in $2 S$ and $3 \mathrm{~S}$ systems. For cost of lean, -FAT was as important as NBA in all except maternal breed roles. For ELA, -DAYS was important in all breed roles, but not for EWW and ELW, especially in maternal breed roles. In ranking paternal breeds for use in $2 \mathrm{~S}$ and $3 \mathrm{~S}$ systems, the important traits were only VIAB for EWW, VIAB and -FAT for ELW, but VIAB, -FAT and -DAYS for ELA. Existing breeds ranked differently as paternal breeds than as maternal or general purpose breeds. Complementary paternal-maternal effects permitted greater cost reductions from best $3 \mathrm{~S}(-7$ to $-10 \%)$ than from best $3 \mathrm{R}$ ( -6 to $-8 \%$ ) breed combinations. Maternal breeds in crosses benefitted from superiority in components of both sow and pig performance. (Key Words: Swine, Efficiency, Breeds, Crossbreeding, Simulation, Systems.)

\section{Introduction}

Breed differences in performance traits affect optimum use of breeds in crossbreeding systems. Knowledge of the relative influence of different traits for each breed role in each breeding system is helpful 1 ) in selecting breeds to maximize breed contributions to efficiency for alternative crossbreeding systems or new composite breeds and 2) in developing efficient within-breed selection procedures for specific breed roles in production systems.

Knowing how heterosis improves efficiency of each crossbreeding system also is useful for comparing alternative crossbreeding systems. Heterosis differences between crossbreeding systems can be combined with breed differences to compare specific crosses for the same or different crossbreeding systems. 
The purposes of this paper are to 1) evaluate the potential contribution of heterosis to efficiency of pork production for alternative crossbreeding systems 2) determine relative importance of performance traits in predicting effects of breed differences on production efficiency for specific breed roles in each breeding system, and 3 ) illustrate applications to the evaluation of specific breed combinations.

\section{Materials and Methods}

Six breeding systems and their replacement populations were simulated to evaluate their economic efficiency. The systems were purebred (P), two-breed specific (2S), backcross (2B), and rotation (2R) crosses, and three-breed specific (3S) and rotation (3R) crosses. The breeding system, replacement populations and terminology used to describe different breed roles in industry systems are shown in table 1. Purebred male-source populations provided their own replacements and surplus boars for use in all other populations. Purebred femalesource populations produced their own replacements and surplus gilts for crossing. Two-breed crosses of purebred parents (2S) were either market pigs or replacement gilts for backcross (2B) or three-breed specific (3S) matings. The $P, 2 R$ and $3 R$ populations produced their own female replacements. All other pigs were reared to a market weight or age. Proportional sizes of populations in each breeding system are shown in table 2. Population size was determined from the number of replacement gilts entering each population per year. Subpopulations that have the same proportion of replacement gilts will produce different numbers of market pigs if breed effects or heterosis levels for components of reproduction are different.

A bioeconomic model of pork production (Tess et al., 1983a) was used to evaluate efficiency of these pork production systems. Management options simulated were $28-\mathrm{d}$ weaning and a maximum of three parities/female, because these were found near optimum by Tess et al. (1983a). A maximum of $70 \%$ of available gilts and boars were used as replacements. The ratio of replacement boars to gilts was 1 to 20 . Replacement population sizes were adjusted accordingly.

Economic inputs and weight outputs were totaled across constituent populations of each breeding system. Total dollar inputs were divided by either total carcass lean or total live

TABLE 1. TERMINAL AND REPLACEMENT POPULATIONS SIMULATED FOR BREEDS (A, B OR C) AND BREED ROLES IN BREEDING SYSTEMS

\begin{tabular}{|c|c|c|c|c|c|}
\hline \multirow[b]{2}{*}{$\begin{array}{l}\text { Breeding } \\
\text { system }\end{array}$} & \multicolumn{3}{|c|}{ Replacement populations } & \multirow[b]{2}{*}{$\begin{array}{l}\text { Terminal-cross } \\
\text { population }\end{array}$} & \multirow[b]{2}{*}{$\begin{array}{l}\text { Breed role } \\
\text { in system }\end{array}$} \\
\hline & $\begin{array}{l}\text { Purebred } \\
\text { male }\end{array}$ & $\begin{array}{l}\text { Purebred } \\
\text { female }\end{array}$ & $\begin{array}{l}\text { Crossbred } \\
\text { female }\end{array}$ & & \\
\hline Purebred (P) & $\mathbf{A}$ & A & & $\mathbf{A} \times \mathbf{A}$ & \\
\hline $\begin{array}{l}\text { Two-breed } \\
\text { specific (2S) }\end{array}$ & $\begin{array}{l}\mathbf{A} \\
\mathbf{B}\end{array}$ & A & & $\mathbf{B} \times \mathbf{A}$ & $\begin{array}{l}\text { A - maternal }(\mathrm{Ma}) \\
\mathrm{B}-\text { paternal }(\mathrm{Pa})\end{array}$ \\
\hline $\begin{array}{l}\text { Two-breed } \\
\text { backcross (2B) }\end{array}$ & $\begin{array}{l}\mathbf{A} \\
\mathbf{B}\end{array}$ & $\mathbf{A}$ & $\mathbf{B} \times \mathbf{A}$ & $\mathbf{A} \times(\mathbf{B} \cdot \mathbf{A})$ & $\begin{array}{l}\text { A -- primary (Pri) } \\
\text { B - secondary (Sec) }\end{array}$ \\
\hline $\begin{array}{l}\text { Two-breed } \\
\text { rotation (2R) }\end{array}$ & $\begin{array}{l}\mathbf{A} \\
\mathbf{B}\end{array}$ & & $\begin{array}{l}B \times\left(\frac{2 A+B}{3}\right) \text { or } \\
A \times\left(\frac{2 B+A}{3}\right)\end{array}$ & $\begin{array}{l}A \times B\left(\frac{2 A+B}{3}\right) \text { or } \\
B \times A\left(\frac{2 B+A}{3}\right)\end{array}$ & \\
\hline $\begin{array}{l}\text { Three-breed } \\
\text { specific (3S) }\end{array}$ & $\begin{array}{l}\mathbf{A} \\
\mathbf{B} \\
\mathbf{C}\end{array}$ & $\mathbf{A}$ & $\mathbf{B} \times \mathbf{A}$ & $\mathrm{C} \times(\mathrm{B} \cdot \mathrm{A})$ & $\begin{array}{c}\text { A - maternal } \\
\text { granddam (MGD) } \\
\text { B - } \text { maternal } \\
\quad \text { grandsire }(\mathrm{MGS}) \\
\mathrm{C}-\text { paternal }(\mathrm{Pa})\end{array}$ \\
\hline $\begin{array}{l}\text { Three-breed } \\
\text { rotation (3R) }\end{array}$ & $\begin{array}{l}\mathbf{A} \\
\mathbf{B} \\
\mathbf{C}\end{array}$ & & $C \times\left(\frac{4 B+2 A+C}{7}\right)^{a}$ & $A \times\left(\frac{4 C+2 B+A}{7}\right)^{a}$ & \\
\hline
\end{tabular}

\footnotetext{
${ }^{a}$ Or one of other two alternative rotation-cross combinations.
} 
TABLE 2. PERCENTAGE OF ALL BREEDING FEMALES USED TO PRODUCE CATEGORIES OF REPLACEMENTS AND MARKET PIGS FOR BREEDS (A, B AND C) AND BREEDING SYSTEMS

\begin{tabular}{|c|c|c|c|c|c|c|}
\hline \multirow[b]{2}{*}{ Categories } & \multicolumn{6}{|c|}{ Breeding system } \\
\hline & $\mathbf{P}$ & $2 S$ & $2 B$ & $2 \mathrm{R}$ & $3 S$ & $3 \mathbf{R}$ \\
\hline A males ${ }^{2}$ & 1.6 & .5 & 1.3 & .8 & .2 & .5 \\
\hline B males ${ }^{a}$ & & 1.1 & .3 & .8 & .3 & .5 \\
\hline C males ${ }^{a}$ & & & & & 1.1 & .5 \\
\hline A fermales ${ }^{a}$ & 31.3 & 31.3 & 9.5 & & 9.5 & \\
\hline$B \times A$ females ${ }^{a}$ & & & 20.2 & & 20.2 & \\
\hline Market pigs & 67.1 & 67.1 & 68.7 & $98.4^{b}$ & 68.7 & $98.4^{b}$ \\
\hline
\end{tabular}

${ }^{\mathbf{a}}$ Plus by-product breeders or market pigs of other sex.

${ }^{\mathrm{b}}$ Includes $31.3 \%$ of crossbred females used to produce rotation crossbred gilt replacements.

weight to determine input/output efficiency ratios, discounting price of surplus sow lean by $21 \%$ and of live weight by $13 \%$ (Tess et al., (1983a). Efficiency of live weight production (EWW) was based on marketing pigs at $100 \mathrm{~kg}$ live weight. Efficiency of carcass lean production was based on marketing pigs either at $100 \mathrm{~kg}$ live weight (ELW) or at the average weight when pigs were $185 \mathrm{~d}$ old (ELA).

The contribution of breed differences to input/output efficiency of each integrated production system was simulated by individually changing breeding value for each component trait of each breed uscd in the breeding system. The genetic contribution of any breed to the performance of a cross was assumed to be proportional to the breed composition of that cross. The range of simulated purebred (additive genetic) breeding values used for each trait is shown in table 3 . These ranges represented about $\pm 10 \%$ from the simulated purebred base value (table 3 ), except for $\pm \sim 5 \%$ in days to 100 $\mathrm{kg}$ (DAYS) and age at puberty (PUB). Protein and fat growth rates were changed iteratively to produce the desired change in DAYS without changing body composition at $100 \mathrm{~kg}$ (FAT), or in FAT without changing DAYS. All component changes were evaluated for marketing at $100 \mathrm{~kg}$ weight (WT). Only DAYS was also evaluated for marketing at average 185 -d weight (AGE) because Tess et al. (1983c) found that these alternative marketing policies made little

TABLE 3. RANGE OF BREEDING VALUES AND MAXIMUM HETEROSIS USED IN SIMULATING EFFECTS ON COSTS OF PORK PRODUCTION FOR EACH TRAIT

\begin{tabular}{|c|c|c|c|c|}
\hline Trait & $\begin{array}{l}\text { Base } \\
\text { purebred } \\
\text { mean }\end{array}$ & $\begin{array}{l}\text { Desired } \\
\text { sign }\end{array}$ & Range & $\begin{array}{l}\text { Maximum } \\
\text { heterosis } \\
\text { ( } \% \text { of pure- } \\
\text { bred mean) }\end{array}$ \\
\hline $\begin{array}{l}\text { Litter size at birth } \\
\text { (NBA) }\end{array}$ & 8.96 & + & \pm .926 & 10.7 \\
\hline $\begin{array}{l}\text { Preweaning viability } \\
\text { (VIAB), \% }\end{array}$ & 71 & + & \pm 7.2 & 11.1 \\
\hline $\begin{array}{l}\text { Age at puberty } \\
\text { (PUB), d }\end{array}$ & 208 & - & \pm 10 & -3.8 \\
\hline $\begin{array}{l}\text { Daily milk energy } \\
\text { (MILK), \% of mean }\end{array}$ & 100 & + & \pm 10 & 25.0 \\
\hline $\begin{array}{l}\text { Conception rate } \\
\text { (CR), \% }\end{array}$ & 72 & + & \pm 7.2 & 4.2 \\
\hline $\begin{array}{l}\text { Empty body fat at } 100 \mathrm{~kg} \\
\text { (FAT) } \%\end{array}$ & 34.2 & - & $\pm \quad 3.5$ & 1.0 \\
\hline $\begin{array}{l}\text { Days to } 100 \mathrm{~kg} \\
\text { (DAYS) }\end{array}$ & 185 & - & \pm 9 & -7.2 \\
\hline
\end{tabular}


difference in the evaluation of other traits. Differences in efficiency included effects of changes in the size of replacement populations.

The effects of the trait range $\left(X_{h}-X_{1}\right)$ simulated for each trait on system efficiency $\left(E_{h}-E_{1}\right)$ was divided by the trait range simulated (table 3 ) to estimate the approximate linear partial regression $\left(b_{i}\right)$ for the effects of breed differences in each trait on each measure of input/output efficiency. Curvilinearity was evaluated from degree of asymmetry for equal trait deviations on either side of the purebred mean. The simulated total effect on production system efficiency for a constituent breed was calculated as the sum of the $\mathbf{n}$ partial effects for each trait [i.e., total effect, $b_{i}\left(X_{i}-X_{j}\right)$ ] added to the mean efficiency $(E)$ for all pure breeds.

The approximate ranges of breeding values for seven traits of six breeds commonly used in the U.S. (table 4) were used to illustrate expected breed effects on production system efficiency. Breeding values were based on a combined analysis of crossbreeding experiments at lowa and Oklahoma (Young et al., 1976a,b; Christenson and Young 1978; Johnson et al., 1978; Schneider, 1978; Gaugler et al., 1981 and personal communication; Hutchens et al., 1982). Breed differences in milk production were approximated by simulating effects of milk production on the estimated breed differences in preweaning viability, adjusted for litter size, recognizing that other maternal traits also may affect viability. Effects of these breed differences on efficiency were combined with average percentage heterosis for the breeding system to compare efficiency of breed combinations for the alternative crossing systems.

Crosses between breeds were assumed to exhibit heterosis in proportion to the expected degree of crossbred heterozygosity. Heterosis levels used were the same (table 3) as in Bennett et al. (1983). Strictly, these linear approximations of breed and heterosis effects on efficiency should not be used to choose particular "best breed combinations" because specific heterosis, curvilinear effects and interactions for trait effects on efficiency were ignored, and because real breed differences change with time and with sampling of breeds.

\section{Results}

Average Effects of Crossing Systems. Mean economic efficiencies for all possible breed combinations in each of the five crossbreeding breeding systems are shown in table 5 as reductions from mean costs for purebreds. Average percentage reductions in cost for breeding systems simulated were least for ELW $(-2.8$ to $-7.5 \%)$, only slightly greater for EWW $[-3.2$ to $-7.9 \%$ and greatest for ELA $(-4.8$ to $-9.5 \%)]$. Breeding systems ranked in the same order for all three marketing policies. The four systems using crossbred females reduced costs 1.4 to 2.7 times as much as first crossing (2S).

TABLE 4. ESTIMATED BREEDING VALUES FOR SEVEN PERFORMANCE TRAITS OF SIX BREED SAMPLESa

\begin{tabular}{|c|c|c|c|c|c|c|c|c|c|}
\hline \multirow[b]{2}{*}{ Traits $b$} & \multirow{2}{*}{$\begin{array}{l}\text { Desired } \\
\text { sign }\end{array}$} & \multicolumn{6}{|c|}{ Breeds } & \multirow[b]{2}{*}{ Range } & \multirow[b]{2}{*}{ Mean } \\
\hline & & $\mathrm{D}$ & $\mathrm{H}$ & $\mathrm{Y}$ & L & $\mathbf{s}$ & $c$ & & \\
\hline NBA & + & .19 & -.30 & .84 & -.37 & -1.83 & 1.47 & 3.30 & 9.8 \\
\hline VIAB, $\%$ & + & -.56 & -7.62 & 2.40 & 5.92 & 4.30 & -4.44 & 13.54 & 68.9 \\
\hline PUB, d & - & 3.95 & -1.55 & 1.65 & -2.75 & -2.95 & $1.65^{\mathrm{c}}$ & 6.90 & 188 \\
\hline MILK, $\%$ of mean & + & -6 & 4 & -1 & 5 & -2 & 0 & 11 & 100 \\
\hline CR, \% & + & -.68 & 5.92 & -6.51 & -5.83 & $1.17^{c}$ & 5.93 & 12.44 & 80.7 \\
\hline FAT & - & & & & & & & & \\
\hline Carcass, $\%$ & & .77 & -4.80 & -.60 & 3.43 & 2.06 & -.94 & 8.23 & 34.5 \\
\hline Back, cm & & .09 & -.56 & -.07 & .40 & .24 & -.11 & .96 & 2.83 \\
\hline DAYS & - & -7.17 & 2.63 & -3.94 & 3.46 & -4.43 & 9.45 & 16.62 & 190.2 \\
\hline
\end{tabular}

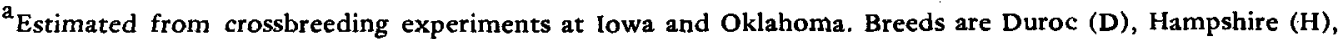
Yorkshire (Y), U.S. Landrace (L), Spot (S) and Chester White (C).

${ }^{b}$ See table 3 for definitions.

${ }^{\mathbf{c}}$ Approximate; no contemporary comparison data.
} 
TABLE 5. AVERAGE REDUCTION (PERCENTAGE) IN TOTAL COST PER $100 \mathrm{KG}$ OF OUTPUT FROM HETEROSIS ALONE, FOR ALL COMBINATIONS OF SIX BREEDS IN FIVE CROSSBREEDING SYSTEMS

\begin{tabular}{llll}
\hline $\begin{array}{l}\text { Breeding } \\
\text { system }\end{array}$ & $\begin{array}{l}\text { EWW } \\
(\$ / 100 \mathrm{~kg} \text { live } \\
\text { Weight @ } 100 \mathrm{~kg})\end{array}$ & $\begin{array}{l}\text { ELW } \\
(\$ / 100 \mathrm{~kg} \text { lean } \\
\text { (100 kg) }\end{array}$ & $\begin{array}{l}\text { ELA } \\
(\$ / 100 \mathrm{~kg} \text { lean } \\
\text { @ 185-d wt) }\end{array}$ \\
\hline P & $\$ 97.43$ & $\$ 186.88$ & $\$ 186.88$ \\
2S & -3.24 & -2.82 & -4.77 \\
2B & -5.84 & -5.59 & -6.82 \\
2R & -6.29 & -5.94 & -7.44 \\
3S & -7.62 & -7.14 & -9.13 \\
3R & -7.94 & -7.54 & -9.47 \\
\hline
\end{tabular}

Both systems using three breeds were better than any using two breeds. For the same number of breeds used, the average of all possible rotation crosses was better than that for backcross or specific combinations. However, the mean advantage of rotation crossing over the best alternative was small and the best three-breed specific crosses surpassed the best three-breed rotations.

Bennett et al. (1983) found that simulated heterosis reduced nonfeed costs more than feed costs. Simulated percentage reductions in mean feed and nonfeed costs per unit of output for all breed combinations in each breeding system are presented in table 6 . Alternative crossbreeding systems ranked the same for nonfeed costs as for feed costs or for total costs $/ \mathrm{kg}$ (table 5). However, average heterosis reduced nonfeed costs proportionately two to nine times more than feed costs for different mating systems. The proportion of the total heterosis cost reduction in EWW and ELW coming from nonfeed sources was about $67 \%$ for $2 S$ and $75 \%$ for other systems, but 86 to $90 \%$ of that in ELA. Marketing at average $185-\mathrm{d}$ weight permits heterosis for growth rate to spread nonfeed (largely sow) costs over more output, but increases feed/gain for market pigs, and thus reduces the over-all feed-cost advantage of crossing systems.

Effects of Traits on Breed Roles in Crossing. Effects on costs $/ 100 \mathrm{~kg}$ for the range in mean performance among the sample of six breeds for each trait (table 4) are shown separately for each breed role in each breeding system for EWW in table 7 and for ELW and ELA in table 8.

The importance of each performance trait

TABLE 6. AVERAGE REDUCTIONS (PERCENTAGE) IN FEED AND IN NONFEED COSTS PER 100 KG OF OUTPUT FROM HETEROSIS ALONE, FOR ALL COMBINATIONS OF SIX BREEDS IN FIVE CROSSBREEDING SYSTEMS

\begin{tabular}{|c|c|c|c|c|c|c|}
\hline \multirow{2}{*}{$\begin{array}{l}\text { Breeding } \\
\text { system }\end{array}$} & \multicolumn{2}{|c|}{$\begin{array}{c}\text { EWW } \\
(\$ / 100 \mathrm{~kg} \text { live } \\
\text { weight } @ 100 \mathrm{~kg})\end{array}$} & \multicolumn{2}{|c|}{$\begin{array}{c}E L W \\
(\$ / 100 \mathrm{~kg} \text { lean } \\
\text { ( } 100 \mathrm{~kg})\end{array}$} & \multicolumn{2}{|c|}{$\begin{array}{c}\text { ELA } \\
\text { (\$/100 kg lean } \\
\text { @ } 185-\mathrm{d} w \mathrm{t}) \\
\end{array}$} \\
\hline & Feed & Nonfeed & Feed & Nonfeed & Feed & Nonfeed \\
\hline $\mathbf{P}$ & $\$ 51.26$ & $\$ 46.17$ & $\$ 98.32$ & $\$ 88.56$ & $\$ 98.32$ & $\$ 88.56$ \\
\hline $\begin{array}{l}2 \mathrm{~S} \\
2 \mathrm{~B} \\
2 \mathrm{R} \\
3 \mathrm{~S} \\
3 \mathrm{R}\end{array}$ & $\begin{array}{l}-2.24 \\
-2.97 \\
-3.32 \\
-4.14 \\
-4.17\end{array}$ & $\begin{array}{r}-4.35 \\
-9.03 \\
-9.59 \\
-11.48 \\
-12.13\end{array}$ & $\begin{array}{l}-1.82 \\
-2.71 \\
-2.96 \\
-3.64 \\
-3.76\end{array}$ & $\begin{array}{r}-3.94 \\
-8.79 \\
-9.26 \\
-10.03 \\
-11.73\end{array}$ & $\begin{array}{r}-.98 \\
-1.99 \\
-2.06 \\
-2.38 \\
-2.48\end{array}$ & $\begin{array}{r}-8.99 \\
-12.17 \\
-13.40 \\
-16.63 \\
-17.22\end{array}$ \\
\hline
\end{tabular}


TABLE 7. SIMULATED TOTAL EFFECTS OF BEST MINUS POOREST BREED, FOR EACH PERFORMANCE TRAIT (TABLE 4) AND BREED ROLE, ON COSTS (\$/100 KG) OF LIVE WEIGHT MARKETED AT $100 \mathrm{KG}$ (EWW), AS PERCENTAGES OF MEAN FOR PUREBREDS (\$97.43)

\begin{tabular}{|c|c|c|c|c|c|c|c|}
\hline \multirow{2}{*}{$\begin{array}{l}\text { Breeding system/ } \\
\text { breed role }\end{array}$} & \multicolumn{7}{|c|}{ Component of performance } \\
\hline & NBA & VIAB & -PUB & MILK & CR & -FAT & -DAYS \\
\hline $\mathbf{P}$ & $-10.47 \mathrm{~b}$ & -7.45 & -.49 & $-.83^{b}$ & -2.87 & $1.62^{\mathrm{f}}$ & $-.12^{b}$ \\
\hline $\begin{array}{l}\text { 2B Pri }(\times 1.33) \\
2 \mathrm{R}(\times 2) \\
3 \mathrm{R}(\times 3)\end{array}$ & $\begin{array}{l}-7.97 c \\
-8.52 \\
-8.07\end{array}$ & $\begin{array}{l}-6.45 \\
-6.08 \\
-5.79\end{array}$ & $\begin{array}{l}-.36 \\
-.42 \\
-.35\end{array}$ & $\begin{array}{l}-.52^{b} \\
-.52^{b} \\
-.46\end{array}$ & $\begin{array}{l}-2.57 c \\
-2.41 \\
-2.29\end{array}$ & $\begin{array}{l}1.50 \mathrm{f} \\
1.14 \mathrm{f} \\
1.34 \mathrm{f}\end{array}$ & $\begin{array}{l}-.57^{b} \\
-.25 \\
-.40\end{array}$ \\
\hline $\begin{array}{l}\text { 2B Sec }(X 4) \\
\text { 3S MGS }(\times 4)\end{array}$ & $\begin{array}{l}-13.83 \\
-12.44 c\end{array}$ & $\begin{array}{l}-7.37 \\
-7.06\end{array}$ & $\begin{array}{l}-.56 \\
-.56\end{array}$ & $\begin{array}{l}-.13 \\
-.49 \mathrm{~b}\end{array}$ & $\begin{array}{l}-3.73 \\
-3.94\end{array}$ & $\begin{array}{l}1.64^{\mathrm{f}} \\
1.21^{\mathrm{f}}\end{array}$ & $\begin{array}{r}-.15 \\
.31 f\end{array}$ \\
\hline $\begin{array}{l}\text { 2S Ma }(X 2) \\
3 S \operatorname{MGD}(\times 4)\end{array}$ & $\begin{array}{l}-17.85^{b} \\
-22.09 c\end{array}$ & $\begin{array}{l}-9.40 \\
-9.54\end{array}$ & $\begin{array}{r}-.92 \\
-1.04\end{array}$ & $\begin{array}{l}-2.46^{b} \\
-1.88^{b}\end{array}$ & $\begin{array}{l}-6.40^{c} \\
-7.94^{c}\end{array}$ & $\begin{array}{l}2.46 \mathrm{df} \\
2.12^{\mathrm{f}}\end{array}$ & $\begin{array}{r}1.19 \mathrm{ef} \\
.99 \mathrm{bf}\end{array}$ \\
\hline $\begin{array}{l}2 \mathrm{~S} \mathrm{~Pa}(\times 2) \\
3 \mathrm{~S} \mathrm{~Pa}(X 2)\end{array}$ & $\begin{array}{l}-.22 \\
-.18\end{array}$ & $\begin{array}{l}-4.82 \\
-4.43\end{array}$ & $\begin{array}{l}-.01 \\
-.01\end{array}$ & $\begin{array}{r}-.01 \\
-.01\end{array}$ & $\begin{array}{l}-.05 \\
-.05\end{array}$ & $\begin{array}{l}.70^{f} \\
.57 \mathrm{f}\end{array}$ & $\begin{array}{l}-.02 \\
-.63^{b}\end{array}$ \\
\hline
\end{tabular}

${ }^{a}$ See table 1 for definitions of breeding systems and breed roles. Effects on costs were multiplied by reciprocal of fraction of breed contribution to genotype of crossbred market pigs ( ), to permit more direct comparisons between breed roles in alternate systems.

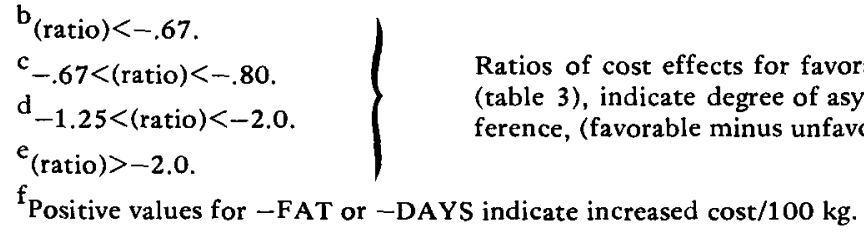

TABLE 8. SIMULATED TOTAL EFFECTS OF BEST MINUS POOREST BREED, FOR EACH PERFORMANCE TRAIT (TABLE 4) AND BREED ROLE ON COSTS (\$/100 KG) OF LEAN AT $100 \mathrm{KG}$ MARKET WEIGHT (ELW) AND AT 185-DAY WEIGHT (ELA), AS PERCENTAGES OF MEAN FOR PUREBREDS (186.88)

\begin{tabular}{|c|c|c|c|c|c|c|c|c|}
\hline \multirow{3}{*}{$\begin{array}{l}\text { Breeding system/ } \\
\text { breed role }\end{array}$} & \multicolumn{8}{|c|}{ Component of performance } \\
\hline & \multirow[b]{2}{*}{ NBA } & \multirow[b]{2}{*}{ VIAB } & \multirow[b]{2}{*}{$-\mathrm{PUB}$} & \multirow[b]{2}{*}{ MILK } & \multirow[b]{2}{*}{ CR } & \multirow[b]{2}{*}{-FAT } & \multicolumn{2}{|c|}{-DAYS } \\
\hline & & & & & & & $\overline{\mathrm{ELW}}$ & ELA \\
\hline $\mathrm{P}$ & $-10.69 b$ & -7.62 & -.47 & $-.82^{b}$ & -3.07 & -10.53 & $-.09 b$ & -3.09 \\
\hline $\begin{array}{l}\text { 2B Pri }(\times 1.33) \\
2 R(X 2) \\
3 R(X 3)\end{array}$ & $\begin{array}{l}-8.15 \mathrm{c} \\
-8.79 \\
-8.53\end{array}$ & $\begin{array}{l}-6.58 \\
-6.28 \\
-6.00\end{array}$ & $\begin{array}{l}-.36 \\
-.41 \\
-.35\end{array}$ & $\begin{array}{l}-.56^{b} \\
-.56^{c} \\
-.50\end{array}$ & $\begin{array}{l}-2.70^{\mathrm{c}} \\
-2.58 \\
-2.44\end{array}$ & $\begin{array}{l}-8.89 \\
-9.31 \\
-8.72\end{array}$ & $\begin{array}{l}-.64 b \\
-.34 \\
-.40\end{array}$ & $\begin{array}{l}-2.75 \\
-2.64 \\
-2.46\end{array}$ \\
\hline $\begin{array}{l}\text { 2B Sec }(x 4) \\
3 S \text { MGS }(\times 4)\end{array}$ & $\begin{array}{l}-14.07 \\
-12.74\end{array}$ & $\begin{array}{l}-7.50 \\
-7.20\end{array}$ & $\begin{array}{l}-.59 \\
-.57\end{array}$ & $\begin{array}{l}-.31 \\
-.65\end{array}$ & $\begin{array}{l}-3.98 \\
-4.13\end{array}$ & $\begin{array}{l}-9.69 \\
-9.21\end{array}$ & $\begin{array}{l}-.10 \\
-.29\end{array}$ & $\begin{array}{l}-2.55 \\
-1.96\end{array}$ \\
\hline $\begin{array}{l}\text { 2S Ma }(\times 2) \\
3 S \text { MGD }(\times 4)\end{array}$ & $\begin{array}{l}-18.38^{c} \\
-22.62^{c}\end{array}$ & $\begin{array}{l}-9.66 \\
-9.76\end{array}$ & $\begin{array}{r}-.90 \\
-1.04\end{array}$ & $\begin{array}{l}-2.39 b \\
-1.99 b\end{array}$ & $\begin{array}{l}-6.67^{c} \\
-8.27^{c}\end{array}$ & $\begin{array}{l}-11.68 \\
-11.50\end{array}$ & $\begin{array}{r}1.04 \mathrm{ef} \\
.97 \mathrm{df}\end{array}$ & $\begin{array}{l}-1.94 \\
-1.72\end{array}$ \\
\hline $\begin{array}{l}2 \mathrm{~S} \mathrm{~Pa}(\times 2) \\
3 \mathrm{~S} \mathrm{~Pa}(\times 2)\end{array}$ & $\begin{array}{l}-.23 \\
-.21\end{array}$ & $\begin{array}{l}-5.00 \\
-4.57\end{array}$ & $\begin{array}{l}-.01 \\
-.01\end{array}$ & $\begin{array}{l}-.02 \\
-.01\end{array}$ & $\begin{array}{l}-.06 \\
-.05\end{array}$ & $\begin{array}{l}-6.86 \\
-7.02\end{array}$ & $\begin{array}{l}-.15 \\
-.76\end{array}$ & $\begin{array}{l}-2.15 \\
-2.74\end{array}$ \\
\hline
\end{tabular}

a,b,c,d,e, $\mathrm{f}_{\text {Same }}$ as footnotes in table 7 , indicating definitions and direction and degree of asymmetrical response. Because responses in ELW and ELA were nearly identical, only the average responses are shown, except for-DAYS. 
(defined in table 3 ) in choosing breeds for crossbreeding is affected by the range in breed performance available to the producer, just as trait importance for within breed selection is affected by its genetic variability. The pattern of breed effects on unit costs was very similar for comparable breed roles.

Effects on cost $/ 100 \mathrm{~kg}$ live weight marketed at $100 \mathrm{~kg}$ (EWW) for primary maternal breed roles (2S $\mathrm{Ma}$ and $3 \mathrm{~S} \mathrm{MGD}$ ) were alike in large cost reductions from increased litter size (NBA), litter viability (VIAB) and higher conception rate (CR), small reductions from more milk output (MILK) and earlier puberty (-PUB), but some increase in costs from less fat (-FAT) and faster growth (-DAYS). Among secondary maternal breed roles (2B Sec and 35 MGS, table 1), the pattern of effects was similar, but MILK and -DAYS were less important and other effects also were smaller, mainly because of smaller numbers in the system (table 2). Relative effects of traits for breeds used in rotation crossing or backcrossing (2R, 3R and 2B Pri) were much like those for secondary maternal roles, except that NBA was relatively less important and-DAYS was mildly beneficial. The pattern of effects was little different for purebreds (P). However, for paternal breeds ( $2 \mathrm{~S}$ or $3 \mathrm{~S} \mathrm{~Pa}$ ) only VIAB was really important, -FAT was mildly detrimental and -DAYS was mildly beneficial only for the $3 \mathrm{~S} \mathrm{~Pa}$ role.

When evaluations were based on cost of lean (ELW, table 8) rather than live weight, importance of reproductive traits was essentially unchanged. However, -FAT became as important as NBA for purebred and rotational roles (P, 2B Pri, 2R, 3R), but less so for secondary or primary maternal (2B Sec, 2S Ma and 3S MGS or MGD) roles. For paternal (2S and $3 \mathrm{~S} \mathrm{~Pa}$ ) breed roles, -FAT became more important than VIAB. Only for costs of lean under 185-d weight marketing (ELA, table 8) did -DAYS become moderately important for all breed roles. Clearly, the choice of breeds for maternal roles depends on many more traits than for paternal roles. Only -FAT, VIAB and -DAYS were important for paternal breeds, whereas these traits plus the components of reproduction were important for purebred, rotation and maternal breeds roles.

Importance of nonlinearity for effects on efficiency were evaluated by taking the ratio of responses to equal favorable and unfavorable changes about the mean of each trait. A ratio of
-1 means that a desired breed trait deviation reduced costs as much as an equally large undesired breed deviation increased costs/unit. One reason for asymmetrical responses is that some trait effects are proportional to their inverse, as is true for litter size. Equal but opposite changes from the mean cause disproportionate changes in the inverse [e.g., (1/12$1 / 10) /(1 / 8-1 / 10)=-.017 / .025=-.67$, tables 7 and 8]. Another reason for asymmetrical response is nonlinear interaction with potential for milk production. Restriction of energy intake in early life can reduce viability, but milk potential in excess of intake requirements cannot increase viability beyond its genetic potential (ratios $<-.67$; tables 7 and 8 ). Consequently, any potential performance change that increases energy requirement in early life will increase mortality if milk is limiting, whereas a change that decreases energy requirement may not decrease mortality.

Increasing litter size (NBA) reduced costs less than decreasing NBA increased costs, particularly for $\mathrm{P}, 2 \mathrm{~S}$ maternal, 2B primary and 3S maternal breed roles (ratios $<-.8$; tables 7 and 8 ). Litter size has an inverse relation with efficiency because its primary effect is to reduce sow costs/pig. However, increasing NBA increases mortality more than reducing NBA lowers mortality. This effect was less evident for breeds used in rotational crossing because heterosis for milk production kept milk energy supply more nearly equal to litter demand. Increased milk also reduced mortality less than decreased milk increased mortality, resulting in asymmetric response for maternal breed roles.

Faster gains (-DAYS) increased preweaning mortality slightly because milk-energy demand exceeded supply. When -DAYS was evaluated by EWW or ELW, this increased mortality sometimes canceled the other small beneficial effects of increased growth rate (2S and $3 \mathrm{~S}$ maternal; tables 7 and 8). However, this asymmetry of response was concealed when -DAYS was evaluated by ELA (185-d marketing) because the increase in total weight of pigs marketed from -DAYS overshadowed its small effects on mortality.

The asymmetric effects of changing conception rate (CR) in breeds whose role is to produce replacement gilts for terminal crossing (2S maternal, $2 \mathrm{~B}$ primary and $3 \mathrm{~S}$ maternal granddam) arose from asymmetric changes in the sizes of the parental source populations. Such parental source populations must provide their 
own replacements before they can provide surplus replacements. The size of the parental source population then was proportional to the inverse of the difference between total potential and parental population numbers of gilt replacements. Number of potential replacement gilts was directly proportional to $\mathrm{CR}+\mathrm{CR}^{2}+$ $\mathrm{CR}^{3}$ because of the three parities in the system. Thus required parental population numbers declined inversely with increased CR (tables 7 and 8).

Importance of $\mathrm{CR}$ was only 25 to $50 \%$ that of NBA in all but paternal breed roles, where $\mathrm{CR}$ was unimportant. The effect was to reduce replacement costs. The other maternal traits, PUB and MILK, were only 5 to $10 \%$ as important as NBA in ranking breeds, even for maternal roles. Milk was somewhat more important for the maternal $2 \mathrm{~S}$ than $3 \mathrm{~S}$ breeds because pig heterosis increased milk energy demand for litters from purebred sows proportionally more than from crossbred sows.

Viability (VIAB) was an important trait in all breeding and marketing systems, including paternal breed roles. The primary effect of VIAB is to divide sow costs among more output. Litter size (NBA) was even more important than VIAB for all breeds except those producing only boars, in which NBA was unimportant.

When market value was based on lean output (ELW or ELA, table 8), -FAT was more important than VIAB for all breed roles and as important as NBA in all but maternal breeds. However, -FAT was moderately detrimental when market value was live weight (EWW, table 7) because of increased sow and pig maintenance costs and higher protein in pig feed. Faster growth (-DAYS) had little beneficial effect when pigs were marketed at $100 \mathrm{~kg}$ live weight, and this small effect was detrimental in maternal breeds because of increased sow maintenance feed costs. However, if pigs were marketed at mean $185-d$ weight, -DAYS was 40 to $50 \%$ as important as VIAB in all except maternal breed roles because nonfeed sow costs were spread over more weight marketed as $185-d$ weight increased.

Results for $P, 2 R$ and $3 R$ were similar to those reported by Tess et al. (1983b) when adjusted for the fact that actual $2 R$ results are one-half and $3 R$ results are one-third of those shown in tables 7 and 8 , because each breed contributes one-half or one-third of the average crossbred market pig genotype. Other small differences are caused by different mean performance levels, especially the lower purebred level for MILK compared with the crossbred level used by Tess et al. (1983a).

Ranking of Breeds for Crossbreeding Roles. To permit prediction of total breed effects on costs of pork production from any set of breed parameters, for differing breed roles in alternative breeding systems, partial regressions on breed means of traits are given for EWW in table 9 and for ELW and ELA in table 10. To illustrate their use, the sample set of breed deviations in table 4 were used. These partial regressions were obtained by dividing the simulated cost effects of approximate breed ranges for each trait (table 3 ) by those ranges. They also correspond to those shown as percentages of the purebred mean in tables 7 and 8 for the total range of sample breed means given in table 4. Differences in backfat were converted to differences in percentage carcass fat by the equation \%FAT $=10.22+8.57 \times$ backfat, $\mathrm{cm}$ (Cleveland, 1981). Total costs are presented only for constant $100 \mathrm{~kg}$ weight marketing of live weight (EWW, table 11) and for constant 185-d age marketing of carcass lean (ELA, table 12). The former (EWW) approximates current U.S. practice and ELA seems the most defensible long-term marketing policy to permit cost reduction from leaner carcasses and faster growth. The breed effects shown have been divided by their fractional contribution to genotype of crossbred progeny, to facilitate comparisons between breeding system roles.

For either EWW and ELA marketing, breed rankings were very similar within related groups of breed roles. Breed rankings for the 2B primary, $2 R$ and $3 R$ were much alike. Values of $\mathrm{L}, \mathrm{S}$ and $\mathrm{C}$ breeds as $2 \mathrm{~B}$ and $3 \mathrm{~S}$ maternal grandsires differ from their $2 B$ Pri, $2 R$ and $3 R$ values because of the greater importance of NBA and VIAB for specific maternal roles. Breed rankings for maternal $2 S$ dam vs $3 S$ granddam differ slightly because of the more critical role of MILK in 2S than 3S, but both differ from 2B and 3S maternal grandsire ranking for $D, S$ and $C$ because of even greater importance of NBA and VIAB for primary maternal breeds. Rankings for the $2 \mathrm{~S}$ and $3 \mathrm{~S}$ paternal roles are nearly identical, but differ sharply from all other system roles in that maternal performance is almost irrelevant.

When marketing at $100 \mathrm{~kg}$ live weight with no premium for lean yield (EWW, table 11), $\mathrm{H}$ ranked poorest as either a paternal or general 
TABLE 9. PARTIAL REGRESSIONSa OF COST PER UNIT (\$/100 KG) OF LIVE WEIGHT MARKETED AT $100 \mathrm{KG}$ (EWW) ON COMPONENTS OF BREED PERFORMANCE

FOR ALTERNATIVE BREED ROLES

\begin{tabular}{|c|c|c|c|c|c|c|c|}
\hline \multirow[b]{2}{*}{$\begin{array}{l}\text { Breeding system/ } \\
\text { breed role } \mathbf{e}^{\mathrm{a}}\end{array}$} & \multicolumn{7}{|c|}{ Component of performance } \\
\hline & NBA & $\begin{array}{l}\text { VIAB, } \\
\%\end{array}$ & $\begin{array}{l}-\mathrm{PUB}, \\
\mathrm{d}\end{array}$ & $\begin{array}{l}\text { MILK, } \\
\% \text { of } \bar{x}\end{array}$ & $\begin{array}{l}\text { DR, } \\
\%\end{array}$ & $\begin{array}{l}-\mathrm{FAT}, \\
\%\end{array}$ & $\begin{array}{l}- \text { DAYS to } \\
100 \mathrm{~kg}\end{array}$ \\
\hline$P$ & $-3.09 \mathrm{~b}$ & -.54 & -.07 & $-.07 \mathrm{~b}$ & -.22 & .19 & $-.01^{b}$ \\
\hline $\begin{array}{l}\text { 2B Pri }(\times 1.33) \\
2 \mathbf{R}(\times 2) \\
3 \mathbf{R}(\times 3)\end{array}$ & $\begin{array}{l}-2.36 \mathrm{c} \\
-2.52 \\
-2.37\end{array}$ & $\begin{array}{l}-.46 \\
-.44 \\
-.42\end{array}$ & $\begin{array}{l}-.05 \\
-.06 \\
-.05\end{array}$ & $\begin{array}{l}-.05^{b} \\
-.05^{b} \\
-.04\end{array}$ & $\begin{array}{l}-.20^{c} \\
-.19 \\
-.18\end{array}$ & $\begin{array}{l}.17 \\
.14 \\
.15\end{array}$ & $\begin{array}{l}-.04^{b} \\
-.01 \\
-.02\end{array}$ \\
\hline $\begin{array}{l}\text { 2B Sec }(x 4) \\
\text { 3S MGS }(\times 4)\end{array}$ & $\begin{array}{l}-4.08 \\
-3.68 \mathrm{c}\end{array}$ & $\begin{array}{l}-.53 \\
-.51\end{array}$ & $\begin{array}{l}-.08 \\
-.08\end{array}$ & $\begin{array}{l}-.01 \\
-.04^{b}\end{array}$ & $\begin{array}{l}-.29 \\
-.31\end{array}$ & $\begin{array}{l}.20 \\
.16\end{array}$ & $\begin{array}{r}-.01 \\
.02\end{array}$ \\
\hline $\begin{array}{l}\text { 2S Mat }(\times 2) \\
\text { 3S MGD }(\times 4)\end{array}$ & $\begin{array}{l}-5.26^{b} \\
-6.52^{c}\end{array}$ & $\begin{array}{l}-.68 \\
-.69\end{array}$ & $\begin{array}{l}-.13 \\
-.14\end{array}$ & $\begin{array}{l}-.22^{b} \\
-.17^{b}\end{array}$ & $\begin{array}{l}-.50^{c} \\
-.62^{c}\end{array}$ & $\begin{array}{l}.30^{b} \\
.24\end{array}$ & $\begin{array}{l}.07^{e} \\
.06^{d}\end{array}$ \\
\hline $\begin{array}{l}\text { 2S Pat }\left(\begin{array}{ll}X & 2\end{array}\right) \\
3 S \text { Pat }\left(\begin{array}{ll}X & 2\end{array}\right)\end{array}$ & $\begin{array}{l}-.06 \\
-.06\end{array}$ & $\begin{array}{l}-.35 \\
-.32\end{array}$ & $\begin{array}{l}-.00 \\
-.00\end{array}$ & $\begin{array}{l}-.00 \\
-.00\end{array}$ & $\begin{array}{l}-.00 \\
-.00\end{array}$ & $\begin{array}{l}.08 \\
.07\end{array}$ & $\begin{array}{l}-.00 \\
-.04 b\end{array}$ \\
\hline
\end{tabular}

${ }^{a}$ See table 1 for definitions of breeding system roles. These regressions correspond to percentage breed ranges for EWW by traits in table 7 , multiplied by $\$ 97.43$, the purebred mean, and divided by the breed range for the trait from table 4. Actual regressions of cost on traits were multiplied by reciprocal of fractions of breed contribution to genotype of market pigs, to permit more direct comparisons between breed roles in alternate systems.

$\mathrm{b}, \mathrm{c}, \mathrm{d}, \mathrm{e}$ Same as footnotes in table 7 , indicating direction and degrees of nonlinearity for the linear approximations shown here.

TABLE 10. PARTIAL REGRESSIONSa OF COST PER UNIT (\$/100 KG) OF LEAN MARKETED AT $100 \mathrm{KG}$ (ELW) OR AT 185-DAY LIVE WEIGHT (ELA) ON COMPONENTS OF BREED PERFORMANCE FOR ALTERNATIVE BREED ROLES

\begin{tabular}{|c|c|c|c|c|c|c|c|}
\hline \multirow{3}{*}{$\begin{array}{l}\text { Breeding system/ } \\
\text { breed role }\end{array}$} & \multicolumn{7}{|c|}{ Component of performance } \\
\hline & & VIAB, & -PUB & MILK, & CR, & $-\mathrm{FAT}$ & -DAYS \\
\hline & NBA & & & $\%$ of $\bar{x}$ & $\%$ & & EWL ELA \\
\hline $\mathbf{P}$ & $-6.05^{b}$ & -1.05 & -.13 & $-.14^{b}$ & -.46 & -2.39 & $-.01^{b}-.35$ \\
\hline $\begin{array}{l}2 B \operatorname{Pri}(X 1.33) \\
2 \mathrm{R}(\times 2) \\
3 \mathrm{R}(X 3)\end{array}$ & $\begin{array}{l}-4.61 c \\
-4.98 \\
-4.74\end{array}$ & $\begin{array}{l}-.91 \\
-.87 \\
-.83\end{array}$ & $\begin{array}{l}-.10 \\
-.11 \\
-.10\end{array}$ & $\begin{array}{l}-.10^{b} \\
-.10^{c} \\
-.08\end{array}$ & $\begin{array}{l}-.41 c \\
-.39 \\
-.37\end{array}$ & $\begin{array}{l}-2.03 \\
-2.12 \\
-1.92\end{array}$ & $\begin{array}{l}-.07 \mathrm{~b}-.31 \\
-.04-.30 \\
-.04-.28\end{array}$ \\
\hline $\begin{array}{l}\text { 2B Sec }(X 4) \\
\text { 3S MGS }(X 4)\end{array}$ & $\begin{array}{l}-7.96 \\
-7.20\end{array}$ & $\begin{array}{l}-1.04 \\
-1.00\end{array}$ & $\begin{array}{l}-.16 \\
-.15\end{array}$ & $\begin{array}{l}-.05 \\
-.11\end{array}$ & $\begin{array}{l}-.60 \\
-.62\end{array}$ & $\begin{array}{l}-2.10 \\
-2.08\end{array}$ & $\begin{array}{ll}-.01 & -.29 \\
-.03 & -.22\end{array}$ \\
\hline $\begin{array}{l}\text { 2S Mat }(\times 2) \\
\text { 3S MGD }(\times 4)\end{array}$ & $\begin{array}{l}-10.40^{c} \\
-12.80^{c}\end{array}$ & $\begin{array}{l}-1.33 \\
-1.35\end{array}$ & $\begin{array}{l}-.24 \\
-.28\end{array}$ & $\begin{array}{l}-.41 b \\
-.34 b\end{array}$ & $\begin{array}{l}-1.00^{c} \\
-1.24^{c}\end{array}$ & $\begin{array}{l}-2.66 \\
-2.60\end{array}$ & $\begin{array}{l}.12^{\mathrm{e}}-.22 \\
.11^{\mathrm{d}}-.19\end{array}$ \\
\hline $\begin{array}{l}\text { 2S Pat }\left(\begin{array}{ll}X & 2\end{array}\right) \\
3 \text { S Pat }\left(\begin{array}{ll}X & 2\end{array}\right)\end{array}$ & $\begin{array}{l}-.13 \\
-.12\end{array}$ & $\begin{array}{l}-.69 \\
-.63\end{array}$ & $\begin{array}{l}-.00 \\
-.00\end{array}$ & $\begin{array}{l}-.00 \\
-.00\end{array}$ & $\begin{array}{l}-.01 \\
-.01\end{array}$ & $\begin{array}{l}-1.56 \\
-1.60\end{array}$ & $\begin{array}{ll}-.02 & -.24 \\
-.09 & -.31\end{array}$ \\
\hline
\end{tabular}

${ }^{a}$ See table 1 for definitions of breeding system roles. Partial regressions correspond to percentage breed ranges for ELW or ELA in table 8 , multiplied by $\$ 186.88$, the purebred mean, and divided by the breed range for the trait from table 4 .

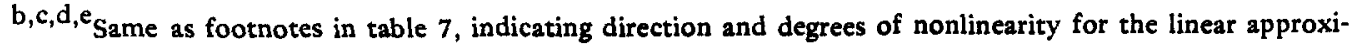
mations shown here. 
TABLE 11. EVALUATION OF SIX BREEDS FOR ALTERNATIVE CROSSBREEDING ROLES, BASED ON \$/100 KG LIVE WEIGHT AT 100 KG MARKETING (EWW)

\begin{tabular}{|c|c|c|c|c|c|c|}
\hline \multirow{2}{*}{$\begin{array}{l}\text { Breeding system/ } \\
\text { breed role }^{\mathbf{a}}\end{array}$} & \multicolumn{6}{|c|}{ Breed $\mathbf{b}$} \\
\hline & D & $\mathbf{H}$ & $\mathbf{Y}$ & $\mathrm{L}$ & $\mathbf{S}$ & $\mathrm{C}$ \\
\hline $\mathrm{P}$ & .38 & 4.21 & -2.15 & -1.90 & 2.61 & -3.14 \\
\hline $\begin{array}{l}\text { 2B Pri }(\times 1.33) \\
2 \mathrm{R}(\times 2) \\
3 \mathbf{R}(\times 3)\end{array}$ & $\begin{array}{l}.04 \\
.20 \\
.06\end{array}$ & $\begin{array}{l}3.72 \\
3.38 \\
3.42\end{array}$ & $\begin{array}{l}-1.68 \\
-1.76 \\
-1.71\end{array}$ & $\begin{array}{l}-1.56 \\
-1.36 \\
-1.35\end{array}$ & $\begin{array}{l}1.51 \\
2.08 \\
1.86\end{array}$ & $\begin{array}{l}-2.03 \\
-2.52 \\
-2.25\end{array}$ \\
\hline $\begin{array}{l}\text { 2B Sec }(X 4) \\
\text { 3S MGS }(X 4)\end{array}$ & $\begin{array}{r}-.12 \\
.40\end{array}$ & $\begin{array}{l}4.32 \\
3.48\end{array}$ & $\begin{array}{l}-2.56 \\
-1.96\end{array}$ & $\begin{array}{l}-.84 \\
-.84\end{array}$ & $\begin{array}{l}4.20 \\
3.80\end{array}$ & $\begin{array}{l}-4.96 \\
-4.88\end{array}$ \\
\hline $\begin{array}{l}2 S \mathrm{Ma}(X 2) \\
3 S \mathrm{MGD}(\times 4)\end{array}$ & $\begin{array}{l}1.82 \\
1.36\end{array}$ & $\begin{array}{l}3.90 \\
3.68\end{array}$ & $\begin{array}{l}-1.90 \\
-2.28\end{array}$ & $\begin{array}{r}-1.82 \\
-.32\end{array}$ & $\begin{array}{l}5.92 \\
7.92\end{array}$ & $\begin{array}{r}-7.88 \\
-10.32\end{array}$ \\
\hline 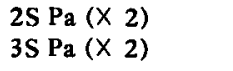 & $\begin{array}{r}.12 \\
-.14\end{array}$ & $\begin{array}{l}3.04 \\
2.84\end{array}$ & $\begin{array}{l}-.82 \\
-.88\end{array}$ & $\begin{array}{l}-2.30 \\
-1.96\end{array}$ & $\begin{array}{l}-1.56 \\
-1.58\end{array}$ & $\begin{array}{l}1.52 \\
1.72\end{array}$ \\
\hline
\end{tabular}

\footnotetext{
${ }^{a}$ See table 1 for definitions of breeding systems and breed roles. Values shown are deviations from mean cost for each system-breed role (table 5) obtained as sum of breed trait deviations (table 4 ) $\times$ corresponding partial regressions (table 9). Effects of breed differences on costs were divided by their fractional contribution to crossbred progeny genotype to permit easier comparison of breed rankings between system roles.

${ }^{b}$ Breeds are Duroc (D), Hampshire (H), Yorkshire (Y), Landrace (L), Spot (S) and Chester White (C).
}

purpose breed and near bottom as a maternal breed. However, for marketing lean at $185-\mathrm{d}$ weight, $H$ ranked second highest as a paternal and third as a general purpose or maternal breed (ELA, table 12). Breed L also changed from ranking first as a paternal breed for marketing live weight to nearly poorest paternal breed for marketing carcass lean. Breed $C$ ranked second for ELA when used in P, 2B Pri, $2 R$ and $3 R$ breeding system roles, but ranked first as a $2 \mathrm{~B}$ or $3 \mathrm{~S}$ secondary maternal breed and especially as a $2 S$ or 35 primary maternal breed, as a result of its high NBA and CR, even though it was poorer than average in -DAYS,

TABLE 12. EVALUATION OF SIX BREEDS FOR ALTERNATIVE CROSSBREEDING ROLES, BASED ON \$/100 KG LEAN AT 185-DAY MARKETING (ELA)

\begin{tabular}{|c|c|c|c|c|c|c|}
\hline \multirow{2}{*}{$\begin{array}{l}\text { Breeding system/ } \\
\text { breed role }\end{array}$} & \multicolumn{6}{|c|}{ Breed $^{b}$} \\
\hline & $\overline{\mathrm{D}}$ & $\mathbf{H}$ & $\mathbf{Y}$ & $L$ & $\mathbf{S}$ & C \\
\hline $\mathbf{P}$ & .44 & -4.17 & -7.05 & 7.01 & 9.27 & -5.71 \\
\hline $\begin{array}{l}\text { 2B Pri }(x 1.33) \\
2 \mathrm{R}(X 2) \\
3 \mathrm{R}(X 3)\end{array}$ & $\begin{array}{l}.20 \\
.30 \\
.24\end{array}$ & $\begin{array}{l}-3.47 \\
-4.08 \\
-3.66\end{array}$ & $\begin{array}{l}-5.59 \\
-5.90 \\
-5.61\end{array}$ & $\begin{array}{l}5.92 \\
6.44 \\
6.00\end{array}$ & $\begin{array}{l}6.72 \\
7.82 \\
7.41\end{array}$ & $\begin{array}{l}-3.96 \\
-4.76 \\
-4.56\end{array}$ \\
\hline $\begin{array}{l}\text { 2B Sec }(X 4) \\
\text { 3S MGS }(X 4)\end{array}$ & $\begin{array}{l}.04 \\
.88\end{array}$ & $\begin{array}{l}-3.48 \\
-4.04\end{array}$ & $\begin{array}{l}-7.44 \\
-6.16\end{array}$ & $\begin{array}{l}8.12 \\
7.32\end{array}$ & $\begin{array}{l}12.32 \\
11.28\end{array}$ & $\begin{array}{l}-9.76 \\
-9.48\end{array}$ \\
\hline $\begin{array}{l}2 S \mathrm{Ma}(\times 2) \\
3 \mathrm{~S} \text { MGD }(\times 4)\end{array}$ & $\begin{array}{l}3.32 \\
2.92\end{array}$ & $\begin{array}{l}-6.74 \\
-7.00\end{array}$ & $\begin{array}{l}-7.06 \\
-7.44\end{array}$ & $\begin{array}{r}8.90 \\
11.12\end{array}$ & $\begin{array}{l}16.70 \\
20.52\end{array}$ & $\begin{array}{l}-15.34 \\
-20.36\end{array}$ \\
\hline $\begin{array}{l}\text { 2S Pa }(X 2) \\
3 \mathrm{~S} \mathrm{~Pa}(X 2)\end{array}$ & $\begin{array}{l}-.14 \\
-.62\end{array}$ & $\begin{array}{l}-1.58 \\
-2.04\end{array}$ & $\begin{array}{l}-3.58 \\
-3.72\end{array}$ & $\begin{array}{l}2.14 \\
2.86\end{array}$ & $\begin{array}{l}-.62 \\
-.60\end{array}$ & $\begin{array}{l}3.64 \\
3.00\end{array}$ \\
\hline
\end{tabular}

\footnotetext{
${ }^{a}$ See table 1 for definitions of breeding system roles. Values shown are deviations from the mean cost for each system (table 5) obtained as sum of trait deviations (table 4) $\times$ corresponding partial regressions (table 10). Effects of breed differences on costs were divided by their fractional contribution to crossbred progeny genotype to permit easier comparison of breed rankings between system roles.

${ }^{b}$ Breeds are Duroc (D), Hampshire (H), Yorkshire (Y), Landrace (L), Spot (S) and Chester White (C).
} 
VIAB and -PUB. Breed $H$ also ranked well above average as a maternal breed for ELA because its below average ranking for NBA, VIAB and -DAYS was offset by higher than average ranking for -FAT, -PUB, MILK and CR. Breed $Y$ was highest for ELA as P, 2B Pri, $2 \mathrm{R}, 3 \mathrm{R}$ and as a $2 \mathrm{~S}$ or $3 \mathrm{~S}$ paternal breed, and second highest among the maternal breeds, without being highest in breeding value for any one trait. Breed $\mathrm{H}$ was second highest $2 \mathrm{~S}$ or $3 \mathrm{~S}$ paternal breed because it was outstanding in -FAT, even though poor in VIAB and -DAYS. The third highest $2 S$ paternal breed (S) was superior in VIAB and -DAYS, but poor in NBA and -FAT. Some breeds (especially S) were higher as paternal than as maternal breeds, but ranked below other breeds in both respects. Even though the characteristics of these six breeds (table 4) were estimated from limited experimental data, the results illustrate the limitations of using any single trait to discriminate among breeds and the potential loss of efficiency from including poorer breeds in a cross-breeding system.

Breed complementarity in specific crossing systems can contribute most to system efficiency when there is low or negative correlation between rankings of breeds for paternal and maternal breed roles. If correlations of breed rankings for different roles are large and positive, differences between specific crosses would depend only on the general ranking of the breeds used. Some correlations between the values of the six sample breeds for different roles are presented in table 13 .

There was little opportunity for breed complementarity between primary and secondary $2 \mathrm{~B}$ crosses or between maternal granddam and grandsire breeds in $3 \mathrm{~S}$ crosses. However,

TABLE 13. CORRELATIONS BETWEEN VALUES OF SIX BREEDS FOR DIFFERENT CROSSBREEDING ROLES

\begin{tabular}{lrrr}
\hline \hline $\begin{array}{l}\text { Breeding system/ } \\
\text { breed role }\end{array}$ & EWW & ELW & ELA \\
\hline 2S Ma and 2S Pa & -.07 & .24 & -.08 \\
2B Pri and 2B Sec & .91 & .98 & .97 \\
3S MGD and 3S MGS & .96 & .99 & .99 \\
3S MGD and 3S Pa & -.30 & .30 & -.10 \\
3S MGS and 3S Pa & -.04 & .26 & .06 \\
\hline
\end{tabular}
roles. complementarity was much more feasible between paternal and other breeds in 2S and 3S breeding systems. The $\mathrm{D}, \mathrm{H}, \mathrm{Y}$ and $\mathrm{L}$ breeds differed relatively little between their paternal and maternal breed effects. Correlations for these breeds were all greater than .80 . The $\mathrm{S}$ and $\mathrm{C}$ breeds had very different effects as maternal and paternal breeds, and are the major contributors to the low correlations in table 13. Possible useful complementarity was limited because VIAB (all), -FAT (ELW and ELA) and -DAYS (ELA) had large beneficial effects on both maternal and paternal performance. Breed superiority in NBA, CR, MILK or -PUB for maternal roles (e.g., breeds $\mathrm{C}, \mathrm{Y}$ of $\mathrm{H}$; table 4) can contribute most to useful complementarity.

Effect of Breed Combinations witbin Breeding Systems. Breed combinations were evaluated by adding the appropriate breed deviation effects to average system efficiency, which includes average additive plus heterosis effects. For example, $\mathrm{D} \times(\mathrm{H} \times \mathrm{Y})$ was evaluted for ELA by adding the breed effects $-.62 / 2$, $-4.04 / 4$ and $-7.44 / 4$ (from table 12) to the system average $\$ 169.81$ (from table 5) to arrive at $\$ 166.63$ as the overall cost of producing 100 $\mathrm{kg}$ of lean. The range of these values within a system as a percentage of the average for the six pure breeds $(\$ 186.88)$ is shown in table 14 .

For all crossbreeding systems, the potential reduction in cost below average purebreds was somewhat greater for lean pork marketed at mean 185-d weight (ELA) than at $100 \mathrm{~kg}$ live weight (ELW) or for live weight at $100 \mathrm{~kg}$ (EWW). This was true for the mean of all possible breed combinations of six breeds (table 5) as well as for the most efficient breed combinations in each system (table 14). Possible advantages from complementary breed differences were indicated by the wider range of efficiencies expected among alternative breed combinations for $2 S$ than for $2 \mathrm{R}(-7$ to -11 vs -5 to $-7 \%)$ and for $3 S$ than for $3 R(-8$ to -9 vs -4 to $-6 \%)$. However, only when the breeding female was crossbred did the most efficient specific crossbreeding combination become potentially superior to the most efficient rotation crossbreeding combination (i.e., 3S $>3 R$ ).

For the six-breed set of breeding values used (table 4), choice of most efficient breed rotations alone reduced costs below average of all combinations by -2 to $-3 \%$ in $3 R$ or $2 R$ systems, but choice of best specific breed 
TABLE 14. RANGES FOR ECONOMIC EFFICIENCY AMONG POSSIBLE

BREEDING SYSTEM COMBINATIONS OF SIX BREEDS, AS A PERCENTAGE OF MEANS FOR PUREBREDS

\begin{tabular}{lllll}
$\begin{array}{l}\text { Breeding } \\
\text { system }\end{array}$ & $\begin{array}{l}\text { No. of } \\
\text { breed } \\
\text { combinations }\end{array}$ & $\begin{array}{l}\text { EWW } \\
(\$ / 100 \mathrm{~kg} \mathrm{live} \\
\text { weight @ } 100 \mathrm{~kg})\end{array}$ & $\begin{array}{l}\text { ELW } \\
(\$ / 100 \mathrm{~kg} \text { lean } \\
\text { @ 100 kg) }\end{array}$ & $\begin{array}{l}\text { ELA } \\
(\$ / 100 \mathrm{~kg} \text { lean } \\
\text { @ } 185 \mathrm{~d})\end{array}$ \\
\hline P & 6 & $96.8-104.3$ & $95.2-105.8$ & $96.2-105.0$ \\
2S & 30 & $91.5-98.8$ & $91.5-102.4$ & $90.2-100.7$ \\
2B & 30 & $91.6-98.1$ & $90.9-98.5$ & $89.6-97.2$ \\
2R & 15 & $91.5-96.5$ & $90.8-97.9$ & $89.7-96.4$ \\
3S & 120 & $88.4-96.2$ & $88.4-96.9$ & $86.6-95.7$ \\
3R & 10 & $90.2-93.9$ & $89.7-95.2$ & $88.4-93.3$ \\
\hline
\end{tabular}

${ }^{\mathrm{a}}$ See table 1 for definitions of breeding system roles.

combination reduced costs by -4 to $-6 \%$ in $3 S$ and $2 \mathrm{~S}$ systems (tables 14 and 5 ).

The efficiency advantage of the best crossbreeding systems over the best pure breed (table 14) is smaller than that of average breed crosses over average purebreds (table 5) for $2 \mathrm{R}$ and $3 R$ rotation crossing $(-4$ to -8 vs -6 to $-10 \%)$, but is the same or greater for $3 \mathrm{~S}$ specific cross combinations $(-7$ to $-10 \%)$.

\section{Discussion}

Several qualifications of the results presented should be emphasized. First, responses from genetic changes in several of the components of performance are nonlinear and thus, their relative importance will depend upon the base level of expression (e.g., litter size, conception rate, milk production). Second, there are joint effects of changes in such components as litter size, viability, growth rate and milk level that also are affected by base levels of expression (Tess et al., 1983b). Third, deviations from average heterosis were ignored. Fourth, the relative importance of different components of breed performance in predicting breed ranking for particular roles in crossbreeding systems was influenced by the assumed genetic ranges in performance traits among six existing breeds, based on available experimental data. Inclusion of additional breeds or correction of errors in breed description could easily change the range and thus, possibly alter the relative importance of traits in ranking breeds. However, validity of using the partial regressions (tables 9 and 10) in preliminary breed rankings would not be altered by changes in breed ranges for traits.

Essentially, the approach used is an elabora- tion and application of a method for approximate evaluation of specific crosses suggested by Smith (1964). As such, it illustrates some principles of breed combination selection brought out by Smith (1964) and Moav (1966a, $b, c)$. Reproduction was found to be of little importance in terminal sire lines. Also, sire-dam heterosis or complementarity was found to be potentially valuable in specific crosses.

One difference from these earlier works is the inclusion of replacement population costs in the evaluation of specific traits. This has at least two consequences. First, productive traits are weighted by 60 to $70 \%$ in female lines instead of $50 \%$ because the female line produces surplus market animals. Second, slightly more emphasis is given to reproduction and viability in specific crosses compared with rotation crosses. This is caused by the higher proportion of purebred sows in the specific-cross systems and the increased proportion of crossbred sows when reproduction in purebred sows is high.

Primarily, this paper was intended to illustrate an approach for predicting the effects of heterosis and breed differences on choice of breeding systems and of breeds for specific roles in those systems. It was not intended to replace potentially more accurate experimental evaluation of particular breeds and crosses. However, such evaluation of particular breeds and crosses does not provide the information necessary to make preliminary evaluations of large numbers of breeds and strains permitted by the production system simulation presented here.

\section{Literature Cited}

Bennett, G. L., M. W. Tess, G. E. Dickerson and R. K. 
Johnson. 1983. Simulation of heterosis effects on costs of pork production. J. Anim. Sci. 56: 792.

Christenson, R. K. and L. D. Young. 1978. Age at first estrus in five breeds of gilts reared in confinement. J. Anim. Sci. 47(Suppl. 1): 351.

Cleveland, E. R. 1981. Effect of lean growth selection and feed intake on composition and energy utilization in swine. Ph.D. Dissertation. Univ. of Nebraska, Lincoln.

Gaugler, H., D. Buchanan, R. Hintz and R. K. Johnson. 1981. Sow productivity comparisons for four breeds of swine in the production of purebred and crossbred litters. J. Anim. Sci. 53(Suppl. 1): 74 .

Hutchens, L. K., R. L. Hintz and R. K. Johnson. 1982. Breed comparisons for age and weight at puberty in gilts. J. Anim. Sci. 55:60,

Johnson, R. K., I. T. Omtvedt and L. E. Walters. 1978. Comparison of productivity and performance for two-breed and three-breed crosses in swine. J. Anim. Sci. 46:69.

Moav, R. 1966a. Specialised sire and dam lines. I. Economic evaluation of crossbreds. Anim. Prod. 8:193.

Moav, R. 1966b. Specialised sire and dam lines. II. The choice of the most profitable parental combinations when component traits are genetically additive. Anim. Prod. 8:203.

Moav, R. 1966c. Specialised sire and dam lines. III. Choice of the most profitable parental combina- tion when component traits are genetically non-additive. Anim. Prod. 8:365.

Schneider, J. 1978. Individual and maternal heterosis estimated from single crosses and backcrosses of swine. Ph.D. Dissertation. Iowa State Univ., Ames.

Smith, C. 1964. The use of specialized sire and dam lines in selection for meat production. Anim. Prod. 6:337.

Tess, M. W., G. L. Bennett and G. E. Dickerson. 1983a. Simulation of genetic changes in life cycle efficiency of pork production. I. A bioeconomic model. J. Anim. Sci. 56:336.

Tess, M. W., G. L. Bennett and G. E. Dickerson. 1983b. Simulation of genetic changes in life cycle efficiency of pork production. II. Effects of components on efficiency. J. Anim. Sci. 56: 354.

Tess, M. W., G, L. Bennett and G. E. Dickerson. 1983c. Simulation of genetic changes in life cycle efficiency of pork production. III. Effects of management systems and feed prices on importance of genetic components. J. Anim. Sci. $56: 369$.

Young, L. D., R. K. Johnson and I. T. Omtvedt. 1976a. Reproductive performance of swine bred to produce purebred and two-breed cross litters. J. Anim. Sci. 42:1133.

Young, L. D., R. K. Johnson, I. T. Omtvedt and L. E. Walters. 1976b. Postweaning performance and carcass merit of purebred and two-breed cross pigs. J. Anim. Sci. 42:1124. 